\title{
Influence of cadmium acetate salt concentration on the composition, structure and morphology of $\mathrm{Cd}_{x} \mathrm{~Pb}_{1-x} \mathrm{~S}$ solid soluton films
}

\author{
I. V. Vaganova ${ }^{1}$, L. N. Maskaeva ${ }^{1,2}$, V.F. Markov ${ }^{1,2}$, V. I. Voronin ${ }^{3}$, V. G. Bamburov ${ }^{4}$ \\ ${ }^{1}$ Ural Federal University named after the first President of Russia B. N. Yeltsin. Mira St., 19. Yekaterinburg, \\ 620002, Sverdlovsk Region, Russia \\ ${ }^{2}$ Ural State Fire Service Institute of Emergency Ministry of Russia. Mira St., 22, Yekaterinburg, 620022, \\ Sverdlovsk Region, Russia \\ ${ }^{3}$ Institute of Metal Physics URAN named after M. N. Miheev. S. Kovalevsloy St., 18, Yekaterinburg, 620137, \\ Sverdlovsk Region, Russia \\ ${ }^{4}$ Institute of Solid State Chemistry URAN, Pervomaiskaya St. 91, Yekaterinburg, 620990, Sverdlovsk Region, \\ Russia \\ irina_vaganova@inbox.ru,mln@ural.ru,v.f.markov@urfu.ru,voronin@imp.uran.ru, bam@ihim.uran.ru
}

DOI 10.17586/2220-8054-2018-9-6-811-822

Films of supersaturated substitutional $\mathrm{Cd}_{x} \mathrm{~Pb}_{1-x} \mathrm{~S}(0.03 \leq x \leq 0.22)$ solutions with a B1-type structure based on lead sulfide cubic lattice were produced by chemical bath co-deposition of $\mathrm{CdS}$ and $\mathrm{PbS}$ with various concentrations of cadmium acetate in the ammonium citrate reaction mixtures. The results of X-ray measurements showed that with increasing cadmium acetate concentration the microstrains increase in the deposited layers and the crystallites have [200] preferred orientation and pronounced volume anisotropy. It is shown that the obtained films are nanostructured. Depending on the solid solution composition, the layers consist of crystallites with average sizes $200-1000$ nm. These, in turn, are formed from initial nanoparticles with diameter $50-70 \mathrm{~nm}$. The conductivity of the films decreases with increasing cadmium-sulfide content. The synthesized films are photosensitive without any special sensitization procedure in the visible and near-infrared spectral ranges. The maximum of spectral characteristic and the long-wave limit of the photo-response of $\mathrm{Cd}_{x} \mathrm{~Pb}_{1-x} \mathrm{~S}$ films move smoothly toward the short-wave spectral range from 3.1 to $1.6 \mu \mathrm{m}$ and from 2.5 to $1.2 \mu \mathrm{m}$, respectively, with an increase in the substitution level of lead into cadmium in $\mathrm{PbS}$ lattice correspondently.

Keywords: chemical bath co-deposition, solid solution films, x-ray diffraction, microstrains, crystallite size.

Received: 2 November 2018

Revised: 7 November 2018

\section{Introduction}

The contemporary state of the rapidly developing optoelectronics and nanoelectronics, sensor production, and solar power engineering arouses considerable interest in $\mathrm{Cd}_{x} \mathrm{~Pb}_{1-x} \mathrm{~S}$ substitutional solid solution thin films of varying compositions. The semiconducting properties of these films are promising as functional materials.

Varying the composition of $\mathrm{Cd}_{x} \mathrm{~Pb}_{1-x} \mathrm{~S}$ substitutional solid solutions allows control of their structure, morphology, and electrophysical properties in a rather wide range, from the wide-bandgap cadmium sulfide $\left(E_{g}=2.42 \mathrm{eV}\right)$ to a comparatively narrow-bandgap lead sulfide $\left(E_{g}=0.41 \mathrm{eV}\right)[1-4]$. The unique optical characteristics of these metal sulfides give access to different spectral ranges of photosensitivity: cadmium sulfide is one of the most effective materials in a visible light spectrum $(500-700 \mathrm{~nm})$ and lead sulfide is characterized by both visible and near-infrared spectral ranges $(400-3100 \mathrm{~nm})$. The variety of the properties for these metal sulfide-forming solid solutions provides rationale for their usage in the fabrication of different electronic devices.

Both individual metal sulfides are challenging materials for solar power engineering. Cadmium sulfide proved to be a suitable material for use as a window layer in solar radiation converters: CdTe/CdS [7-9] and CIGS/CdS [10]. Lead sulfide is effectively used as an absorbing material [11]. Therefore, recently, there has been observed an increasing interest in creation and investigation of thin film heterostructures with the $p-n$ transition in the $\mathrm{CdS}-\mathrm{PbS}$ system for production of solar cells $[11,12]$. It was observed that, a solar cell with the structure ITO/CdS/PbS, covered with a transparent conductive layer of ITO (indium tin oxide), was observed to be more promising conversion efficiency compared with some other similar solar cells [12]. In addition, an enhanced conversion efficiency of $3.10 \%$ was demonstrated for $\mathrm{PbS} / \mathrm{CdS}$ thin film solar cells without the involvement of quantum dots by focusing on the origin of the enhancement [13].

A thin film solar cell in which chemically deposited layer of cadmium sulfide was doped with silver ITO/CdS$\mathrm{Ag} / \mathrm{PbS} /$ graphite operates in a spectral range from visible to near-infrared spectral ranges and is characterized by a short circuit current of $85.2 \mathrm{~mA}$, maximum voltage of $0.6 \mathrm{~V}$, and maximum power of $26.3 \mu \mathrm{W}$ [14]. The efficiency 
of ITO/Cu-CdS/PbS/Ag solar cells on the glass substrate increased from $0.52 \%$ to $1.38 \%$ with an increase in the PbS film thickness from 528.3 to $1250.8 \mathrm{~nm}$ [15].

It was proved that for the absorbing semiconducting layer in solar cells, the optimum bandgap width is $1.5 \mathrm{eV}$, which can be achieved by production of solid solutions in the form of ternary $\mathrm{Cd}_{1-x} \mathrm{~Pb}_{x} \mathrm{~S}$ compounds [16]. By varying their composition, the optical and semiconducting properties can be optimized, thus providing an efficiency coefficient of conversion of more than $40 \%$.

It was determined that thin films of pure cadmium sulfide are not stable with respect to the photoconductivity (the experiment was performed over two years) compared to the solid $\mathrm{Pb}_{x} \mathrm{Cd}_{1-x} \mathrm{~S}$ solutions [6] and those based on them [17]. In certain conditions, due to limited mutual solubility of CdS and PbS [18], lead ions are displaced on the surface of the film. In this way, the CdS-PbS material was designated which consists of a wide bandgap matrix with a solid solution of $\mathrm{PbS}$ into $\mathrm{CdS}$, and narrow bandgap low resistant inclusions of solid solution of $\mathrm{CdS}$ into PbS [19]. According to the previous work [20], the lead content in the wide bandgap matrix is not higher than 2 atom $\%$. Generation processes occur predominantly in the wide bandgap matrix, and the recombination is largely related to the narrow bandgap inclusions. In particular, it is confirmed by the data on the film luminescence in the infrared range [21]. Additionally, it is noted that polycrystal layers based on the heterogeneous material CdS- $\mathrm{PbS}$ have another useful property such as high photosensitivity [19].

One more characteristic of heterogeneous compounds in the CdS-PbS system is their high irradiation stability [22-24]. Exclusively high irradiation stability (to $108 \mathrm{R}$ ) of detectors was observed based on the $\mathrm{Cd}_{x} \mathrm{~Pb}_{1-x} \mathrm{~S}$ solid solution films [6]. It allows their use in radiation hazardous facilities experiencing both constant and spontaneous radiation loads.

As-deposited $\mathrm{Cd}_{x} \mathrm{~Pb}_{1-x} \mathrm{~S}$ thin film solid solutions are characterized by anomalously high level of photo response in the visible and near-infrared spectral range without using sensitization methods at relatively low time constant values. This allows employment of these compounds to produce highly-sensitive fast photo detectors [25]. The challenge of using $\mathrm{Cd}_{x} \mathrm{~Pb}_{1-x} \mathrm{~S}$ nanocrystal as a material for distant earth sounding in the infrared spectral range, and detecting natural or man-made objects radiating at wavelengths of $400-3100 \mathrm{~nm}$ [5].

Ternary thin film compounds in the PbS-CdS system are polycrystalline and have a limited range of mutual solubility based on both a cubic structure of the sphalerite type (space group $F \overline{4} 3 m$ ) and a hexagonal structure of the wurtzite type (space group $P 6_{3 m c}$ ) on the side of $\mathrm{CdS}$ and a cubic structure of the halite type (modification $B 1)$ on the side of $\mathrm{PbS}[26,27]$.

According to the high temperature phase diagram of the pseudo binary PbS-CdS system [28], the solubility of CdS in the lead sulfide at $873 \mathrm{~K}$ is $\sim 4.5 \mathrm{~mol} . \%$ and for the lead sulfide in CdS, less than $0.1 \mathrm{~mol} . \%$ even at $1203 \mathrm{~K}$. Therefore, it can be suggested that at below $373 \mathrm{~K}$, the solubility of $\mathrm{CdS}$ in the galena $\mathrm{PbS}$ is negligible and $\mathrm{PbS}$ in the sphalerite $\mathrm{CdS}$, practically non-existent.

However, by "soft chemistry" methods it may be possible to obtain supersaturated PbS-CdS substitutional solutions with much wider ranges of compositions than the corresponding results of the high temperature phase diagrams at any temperature. Vesnin reported the possibility of low-temperature formation of supersaturated substitutional solid solutions in view of the low activation energy values for this process [29,30]. Such phases are thermodynamically unstable due to either kinetic obstacles or any other features of the system often are retained for indefinite periods at relatively high temperatures. That is why it may be possible to produce substitutional solid solutions with different compositions, whose formation is impossible under equilibrium conditions.

In particular, according to the literature data, the use of the colloid chemical method of solid solution synthesis $\mathrm{Cd}_{x} \mathrm{~Pb}_{1-x} \mathrm{~S}$ allows one to produce compounds quite enriched in the substitutional component at a temperature below $373 \mathrm{~K}$. Thus, at $353 \mathrm{~K}$ the $\mathrm{Cd}_{x} \mathrm{~Pb}_{1-x} \mathrm{~S}$ films with the $\mathrm{CdS}$ content up to $16 \mathrm{~mol} \%$ were produced by the chemical bath deposition [31,32]. Markov et al. reported the synthesis of the $\mathrm{Cd}_{x} \mathrm{~Pb}_{1-x} \mathrm{~S}$ film with the $\mathrm{CdS}$ content up to $21 \mathrm{~mol} . \%$. [33,34].

Colloid chemical methods for the production of solid solutions (CDB) are quite popular today. Thus, in previous work [35], the authors managed to produce $\mathrm{Cd}_{x} \mathrm{~Pb}_{1-x} \mathrm{~S}$ solid solution films with the maximum fraction of lead substituting for cadmium in the crystal lattice of $\mathrm{PbS}$, which is equal to 0.15 , by chemical deposition from the citrated ethylenediamine system with varying temperature, $\mathrm{pH}$, and reagents. Recently, it was reported that the synthesized $\mathrm{Cd}_{x} \mathrm{~Pb}_{1-x} \mathrm{~S}$ solid solution films with a value of $x$ of up to 0.21 are highly supersaturated and metastable [31-34,36,37]. As a consequence, the continuous contraction of the lattice with increasing cadmium content is shown to be evidence for the formation in nanocrystals of ternary $\mathrm{Cd}_{x} \mathrm{~Pb}_{1-x} \mathrm{~S}$ compounds, and also the researches considered changes in the properties of the synthesized films $[38,39]$. Thus, the deposited $\mathrm{Pb}-\mathrm{Cd}-\mathrm{S}$ films, enriched in cadmium, have a high absorption coefficient $\left(10^{4} \mathrm{~cm}^{-1}\right)$ and direct type of transition with the bandgap width that is continuously decreasing from 2.47 to $0.49 \mathrm{eV}$ with an increase in the lead content [39]. 
In most publications, it is noted that in order to provide suitable functional properties (photoluminescence, photosensitivity), their sensitization requires thermal annealing of the as-deposited $\mathrm{Cd}_{x} \mathrm{~Pb}_{1-x} \mathrm{~S}$ solid solution layers under aerobic conditions. It was observed that after annealing of chemically deposited $\mathrm{Cd}_{0.5} \mathrm{~Pb}_{0.5} \mathrm{~S}$ films, the structural, morphological and optical properties were changed. In particular, the bandgap width of the samples decreased from 2.6 to $2.05 \mathrm{eV}$ [40]. With an increase in annealing temperature to $573 \mathrm{~K}$, the decreasing of bandgap width is observed from 1.59 to $1.55 \mathrm{eV}$ and from 1.70 to $1.65 \mathrm{eV}$ for $\mathrm{PbS}$ and $\mathrm{Cd}_{0.4} \mathrm{~Pb}_{0.6} \mathrm{~S}$, respectively [41].

From the literature [42], it was observed that $\mathrm{Cd}_{x} \mathrm{~Pb}_{1-x} \mathrm{~S}$ layers $(0<x \leq 1)$ were produced by chemical deposition on glass substrates, in addition, it was also proved that their structural, electrical, and photoelectrical properties depended on the composition. At $x>0.5$ (high CdS content), the films demonstrate weak crystallinity and low photoconductivity; at $x<0.5$ (high $\mathrm{PbS}$ content), the films have a good crystallinity with an average crystallite size of $100 \mathrm{~nm}$ and higher photoconductivity. The increasing cadmium sulphide content leads to the spectra-response displacement into the short-wave region. The experimental results demonstrate the possibility of forming substitution $\mathrm{Cd}_{x} \mathrm{~Pb}_{1-x} \mathrm{~S}$ solid solution in the vicinity of compositions of individual $\mathrm{PbS}$ and $\mathrm{CdS}$ on a certain segments of the layer, whereas the main segment of the deposited film, in authors' opinion, may rather be a mixture of sulfide phases $(\mathrm{CdS})_{x}(\mathrm{PbS})_{1-x}$.

The chemical bath deposition of enriched $\mathrm{Cd}_{x} \mathrm{~Pb}_{1-x} \mathrm{~S}$ solid solution films can be predicted and allows one to formulate clear recommendations for synthetic control [33]. The conditions of metastable structure formation of cadmium content $\mathrm{Cd}_{x} \mathrm{~Pb}_{1-x} \mathrm{~S}$ solid solutions at low temperature hydrochemical synthesis is influenced by the following factors: metal salt content in the reaction mixture, complexing agent content, temperature, $\mathrm{pH}$, time of deposition, and a number of other conditions of the process (features of the nucleation, substrate material, and external factors). To evaluate the composition of chemically deposited $\mathrm{Cd}_{x} \mathrm{~Pb}_{1-x} \mathrm{~S}$ films on the side of $\mathrm{PbS}$, previous researchers [31] suggested using such an integrated index as the ratio of concentrations of the off-complex ions of lead and cadmium in the reaction mixture: $[\mathrm{CdS}]_{T P}$, mol. $\%=f\left(\left[\mathrm{~Pb}^{2+}\right] /\left[\mathrm{Cd}^{2+}\right]\right)$. In the reaction mixture, these metal salts were introduced in the form of lead acetate $\mathrm{Pb}(\mathrm{OAc})_{2}$ and cadmium chloride $\mathrm{CdCl}_{2}$. For the hydrochemical production of the $\mathrm{Cd}_{x} \mathrm{~Pb}_{1-x} \mathrm{~S}$ solid solutions, only metal acetate salts were used in various concentration ratios $[3,40,41,43-45]$. The influence of anion component of the used lead and cadmium salts on chemical and phase composition, structure, and properties of solid solutions formed was not discussed in these previously reported works. At the same time, in our previous work [33], we observed that the nature of anions of introduced metal salts is an important factor, which influences composition and microstructure of the deposited solid solutions.

The influence of the anion background of the area on the crystallization in films is quite well known; additionally, the impurity nature [46], including the anion nature, significantly influences the composition and morphology of microcrystals. Thus, using spray-pyrolysis, the substitution of cadmium chloride by acetate under equal conditions allows one to double the thickness of CdS films [47]. However, the role of the anion component of the cadmium salt in the crystallization process was not thoroughly studied. In our previous study [33], we showed that the use of the cadmium acetate for the film synthesis under other equal conditions results in an increase in the CdS content to $0.4-4.0$ mol.\% (compared to $\mathrm{CdCl}_{2}$ ). This result and the revealed change in the film morphology are connected with the active influence of the anion background of the reaction mixture on the formation of solid solutions. It was suggested that the obtained results depend on the various reaction capacity of thiourea used for the chemical deposition of solid solutions, which forms an intermediate complex due to the anion's nucleophilic addition to carbon atom $[33,48]$. It is obvious that the stability of the intermediate complex will depend not only on the strength of the thiourea complex with metal but also on nucleophilic properties of the added anion. The increasing anion nucleophilicity upon transferring from chloride to acetate ions will lead to increasing the reaction capacity of the activated thiourea due to the weakening of the carbon-sulfur bond. The increasing reaction capacity of thiourea will influence mostly the speed of the CdS phase formation due to the high polarization of the carbon-sulfur bond with cadmium. Finally, it will influence the redistribution of the speed of formation of individual sulphides in favor of the latter, and will increase its fraction in the solid solution composition.

In the literature, there are no detailed studies of the influence of concentration of the cadmium acetate salt on composition and structure of the $\mathrm{Cd}_{x} \mathrm{~Pb}_{1-x} \mathrm{~S}$ solid solution films deposited from aqueous solutions. Therefore, the purpose of this research is the chemical bath synthesis of $\mathrm{Cd}_{x} \mathrm{~Pb}_{1-x} \mathrm{~S}$ films on glass-ceramic substrates, study of their composition, morphological and structural features, and photoelectric properties depending on the cadmium acetate content in the reaction bath.

\section{Experimental details}

Film deposition in the PbS-CdS system was performed in citrated-ammonium reaction mixture on the preliminary degreased glass-ceramic substrates with a surface of $30 \times 30 \mathrm{~mm}$. Cadmium acetate $\mathrm{Cd}(\mathrm{OAc})_{2}$ was used as 
the cadmium salt and introduced into the reaction mixture. The concentration of $\mathrm{Cd}(\mathrm{OAc})_{2}$ was varied from 0.01 to $0.1 \mathrm{~mol} / \mathrm{l}$, whereas the concentration of the lead acetate $\left(\mathrm{Pb}(\mathrm{OAc})_{2}\right)$ was constant and equal to $0.02 \mathrm{~mol} / \mathrm{l}$ in the reaction mixture. Chemical deposition was made in the presence of complex-forming agents: using aqueous ammonia for cadmium and sodium citrate $\left(\mathrm{Na}_{3} \mathrm{C}_{6} \mathrm{H}_{7} \mathrm{O}_{8}\right)$ for lead. The initial concentration of thiourea $\left(\mathrm{N}_{2} \mathrm{H}_{4} \mathrm{CS}\right)$ in the reaction mixture was $0.58 \mathrm{~mol} / \mathrm{l}$ in all experiments. The film synthesis was carried out at $353 \mathrm{~K}$ for $120-$ 140 minutes in the sealed reactors of molybdenum glass where substrates were fixed in special teflon devices. The reactors were placed into thermostat TS-TB-10 with an accuracy of the temperature control of $\pm 0.1^{\circ}$.

The thickness of the synthesized layers was estimated using a Linnik interference microscope MII-4.

The crystal structure of the synthesized solid solution $\mathrm{Cd}_{x} \mathrm{~Pb}_{1-x} \mathrm{~S}$ films was studied by X-ray diffraction method using a diffractometer Dron-4 with copper anode in Bragg-Brentano geometry. The separation of $\mathrm{CuK} \alpha_{1,2^{-}}$ doublet line from the continuous spectrum was made using a monochromator made from pyrolytic graphite with the reflecting plane (002). The experimental XRD patterns were obtained in an angular range from 20 to 100 degrees with a step of $0.02^{\circ}$ and exposure of $5-10$ seconds per point. The samples were rotated in a vertical plane. The analysis of experimental spectra was made by the Rietveld full-profile analysis [49] using software package FullProf [50]. A Pseudo-Voigt function was used to describe reflection profiles. Corrections for errors in the sample setting and deflection of sample plane from the scattering plane were applied for the description of the whole diffraction spectrum. Also, while analyzing the scaling factor, the reflection width and shape, lattice parameters, and atom coordinates were varied. Corrections for the thermal oscillation of atoms and possible deflection of the values of the lattice site occupation were also applied. To calculate the reflection broadening due to the smaller coherent scattering regions (CSR) or internal microstrains, we used the instrumental angular dependence obtained on polycrystalline sample of the cerium oxide, which was preliminary annealed at $1200{ }^{\circ} \mathrm{C}$ for 12 hours. The evaluation of grain sizes (CSR) and microstrains was made by the Williamson-Hall method [51,52] using the dependence of the physical broadening $\beta \cdot(2 \theta)=\beta(2 \theta) \cos \theta / K_{h k l} \lambda$ on the scattering vector length $s=2 \sin \theta / \lambda$. The same possibility was input in the software package FullProf [50].

The investigation of structural and morphological characteristics and elemental composition of the obtained films was fulfilled by raster electron microscopy using a MIRA3LMV microscope at an accelerating voltage of the electron beam of $10 \mathrm{kV}$, and a raster electron microscope JEOL JSM-5900 LV with the attachment for the energy-dispersion (EDX) analysis (EDS Inca Energy 250). The error for the elemental composition was about $10 \%$.

Investigation of optical properties of the solid solution films was carried out on the samples preliminary covered with nickel contacts by the electro-chemical method.

Relative spectral characteristics of photosensitivity were obtained using a double monochromator SPM-2 at a radiation modulation frequency of $400 \mathrm{~Hz}$, whose single-frequency measuring channel was the same as the measuring channel of the UFI-1 device [53]. A halogen incandescent lamp KGM-12-100 was used as the radiation source, while its mode of operation on current was stabilized with an accuracy of $\pm 0.2 \%$. Spectra were recorded automatically in the wave-length range $0.4-3.5 \mu \mathrm{m}$ with $0.05 \mu \mathrm{m}$ increments.

\section{Results and discussion}

Over the whole range of the cadmium acetate concentrations employed in the reaction mixture in the $\mathrm{PbS}-\mathrm{CdS}$ system, and polycrystalline films with the $0.6-1.2 \mu \mathrm{m}$ thickness were obtained.

In the XRD patterns of the films obtained by co-deposition of $\mathrm{PbS}$ and $\mathrm{Cd}$, reflections of two phases are observed - of lead sulfide with the B1-type cube structure (space group $F m \overline{3} m$ ) and of glass-ceramic substrate (Fig. 1).

Increasing the cadmium content in the reaction solution from 0.01 to $0.10 \mathrm{~mol} / \mathrm{l}$ was followed by the decreasing of the lattice constant for the PbS phase from 0.59242 (1) to 0.58918 (1) nm (inset in Fig. 1), which exceeds the lattice constant of the cube lead sulfide $(0.5932 \mathrm{~nm})$. We ascribed it to substitutional $\mathrm{Cd}_{x} \mathrm{~Pb}_{1-x} \mathrm{~S}$ solid solutions formed on the side of $\mathrm{PbS}$. The decreasing of the lattice constant upon the solid solution formation results from the substitution of lead ions $\mathrm{Pb}^{2+}$ with a radius of $0.120 \mathrm{~nm}$ in the $\mathrm{PbS}$ lattice by smaller cadmium ions $\mathrm{Cd}^{2+}$ with a radius of $0.097 \mathrm{~nm}$. The cadmium sulfide content in the solid-solution films was calculated using Vegard's law. It is valid with rather a high accuracy for chalcogenide systems [54]. The lattice constant of CdS film produced from the ammonium-citrated bath was $a_{\mathrm{CdS}}=0.5761 \mathrm{~nm}$. According to the estimation, the maximum content of cadmium sulfide in the solutions with the lattice constants 0.59242 (1), 0.59187 (1), 0.59094 (1), 0.58951 (1), 0.58918 (1) nm was 3.0, 6.0, 12.0, 20.0, and $22.0 \mathrm{~mol} \%$, respectively. The compositions of the solid solutions produced can be defined as $\mathrm{Cd}_{0.03} \mathrm{~Pb}_{0.97} \mathrm{~S}, \mathrm{Cd}_{0.06} \mathrm{~Pb}_{0.94} \mathrm{~S}, \mathrm{Cd}_{0.12} \mathrm{~Pb}_{0.88} \mathrm{~S}, \mathrm{Cd}_{0.20} \mathrm{~Pb}_{0.80} \mathrm{~S}, \mathrm{Cd}_{0.22} \mathrm{~Pb}_{0.78} \mathrm{~S}$. It means that the cadmium concentration in the supersaturated solid solutions under study is within the range from 3.0 to $22.0 \mathrm{~mol} . \%$ and gradually increases with the increase in the cadmium acetate concentration in the reaction 


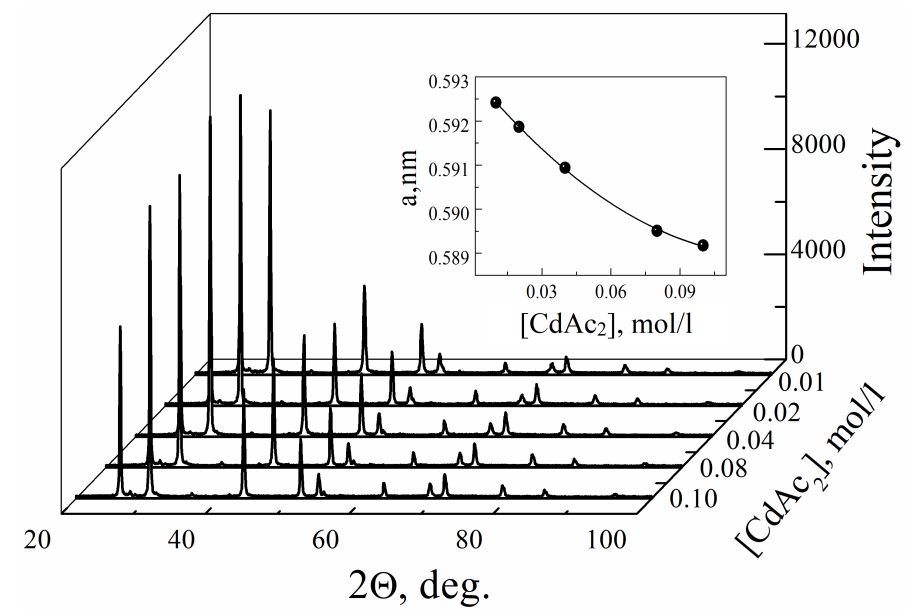

FIG. 1. XRD patterns of $\mathrm{Cd}_{0.03} \mathrm{~Pb}_{0.97} \mathrm{~S}, \mathrm{Cd}_{0.06} \mathrm{~Pb}_{0.94} \mathrm{~S}, \mathrm{Cd}_{0.12} \mathrm{~Pb}_{0.88} \mathrm{~S}, \mathrm{Cd}_{0.20} \mathrm{~Pb}_{0.80} \mathrm{~S}$, $\mathrm{Cd}_{0.22} \mathrm{~Pb}_{0.78} \mathrm{~S}$ films, produced by co-deposition of cadmium and lead sulfides at $T=353 \mathrm{~K}$ for 140 minutes from the reaction mixture containing $0.01,0.02,0.04,0.06,0.08,0.10 \mathrm{CdAc}_{2} \mathrm{~mol}_{1}$. All the XRD patterns contain only reflections of the cubic phase with the $B 1$-type structure and solid-solution composition was estimated based on the lattice constant. The change in the lattice constant depending on the cadmium acetate concentration in the reaction mixture is shown in the inset

mixture from 0.01 to $0.10 \mathrm{~mol} / \mathrm{l}$. The comparison of the obtained results with the phase diagram of the system $\mathrm{PbS}-\mathrm{CdS}$ [28] shows a significant supersaturation of the synthesized solid solutions with cadmium.

Figure 2 shows an XRD pattern of the $\mathrm{Cd}_{x} \mathrm{~Pb}_{1-x} \mathrm{~S}$ film produced by deposition from the reaction mixture containing $0.01 \mathrm{~mol} / \mathrm{l}$ of cadmium acetate, the composition of solution containing $0.02 \mathrm{~mol} / 1 \mathrm{PbAc} 2,4.5 \mathrm{~mol}_{2} / 1$ $\mathrm{NH}_{4} \mathrm{OH}, 0.3 \mathrm{~mol} / 1 \mathrm{Na}_{3} \mathrm{C}_{6} \mathrm{H}_{5} \mathrm{O}_{7}$ and $0.58 \mathrm{~mol} / 1 \mathrm{~N}_{2} \mathrm{H}_{4} \mathrm{CS}$. The analysis showed that the basic reflections refer to the cube phase with the potential symmetry groups $F m \overline{3} m$ or $F \overline{4} 3 m$. Along with these reflections, additional reflections were also observed which refer to the tetragonal phase $\mathrm{TiO}_{2}$. It is associated with the fact that the solid-solution film $\mathrm{Cd}_{x} \mathrm{~Pb}_{1-x} \mathrm{~S}$ was condensed on the substrate made of glass-ceramic, which contains the titanium oxide $\mathrm{TiO}_{2}$. The sulphide $\mathrm{PbS}$ crystallizes in the $\mathrm{NaCl}$ type structure (B1-phase), but also, under certain conditions, it can have the wurtzite-type structure (B3-phase) [55]. As the CdS phase has a cube structure of the wurtzite-type, we verified both models for the solid solutions obtained. The calculations showed that the obtained sample has the B1-type structure. However, at the same time, we found that the experimental intensity of reflection (200) is slightly higher than the calculated one. This can be associated with the formation upon deposition of a bulk polycrystalline state in which a certain ordering (texture) of grains perpendicular to the substrate surface is prevailed.

Figure 3 shows the segments of the XRD patterns (reflections (111) and (200)) of $\mathrm{Cd}_{x} \mathrm{~Pb}_{1-x} \mathrm{~S}$ solid-solution films produced from the reaction bath containing $0.01,0.02,0.04,0.08,0.1 \mathrm{~mol} / 1$ of cadmium acetate. The difference in the ratio of intensities of diffraction peaks (111) and (200) in the XRD patterns, which clearly manifests itself upon increasing the cadmium acetate concentration, is associated with the preferable orientation of grains along the crystallographic direction (200), which is perpendicular to the substrate surface in the films under study.

Introduction in the analysis of experimental data of texture provides an adequate description of the experimental profile in the XRD pattern of the $\mathrm{Cd}_{0.20} \mathrm{~Pb}_{0.80} \mathrm{~S}$ solid-solution film. The same method was used for the description of other XRD patterns in which a good correlation with the experiment was also obtained (Fig. 3(a-e)). Fig. 3(f) shows the dependence of volume of the randomly orientated material P1 on the cadmium acetate concentration in the solution. It has been seen that, in general, the texture degree decreases with the increase in the cadmium salt content $\mathrm{Cd}(\mathrm{OAc})_{2}$ in the reaction mixture, except for the last point 0.1 .

The structure refinement for the solid solutions with the correction of selected reflections (111) and (200) by the software package FullProf [50] is provided on the $\mathrm{Cd}_{0.20} \mathrm{~Pb}_{0.80} \mathrm{~S}$ solid-solution film produced from the reactor containing $0.08 \mathrm{~mol} / \mathrm{l}$ of cadmium acetate within two models, without and with account for the preferable orientation (Fig. 4).

There is a shift to the range of the reflections observed in the XRD patterns of all the studied $\mathrm{Cd}_{x} \mathrm{~Pb}_{1-x} \mathrm{~S}$ solid-solution films (Fig. 1), as well as their broadening due to either decrease in the grain size or appearance of 


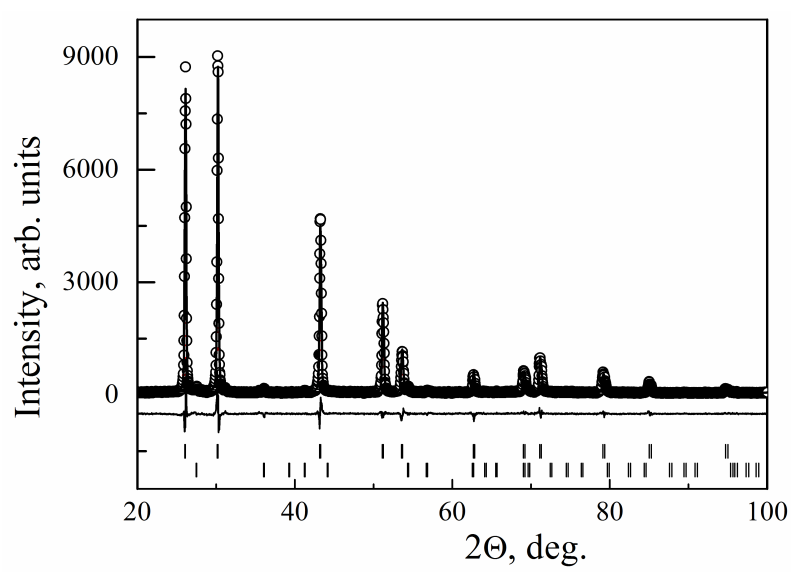

FIG. 2. XRD pattern of $\mathrm{Cd}_{x} \mathrm{~Pb}_{1-x} \mathrm{~S}$ film produced by chemical deposition from the reaction mixture containing $0.01 \mathrm{~mol} / 1$ of cadmium acetate in a composition of $0.02 \mathrm{~mol} / 1 \mathrm{PbAc}_{2} 4.5 \mathrm{~mol} / 1$ $\mathrm{NH}_{4} \mathrm{OH}, 0.3 \mathrm{~mol} / 1 \mathrm{Na}_{3} \mathrm{C}_{6} \mathrm{H}_{5} \mathrm{O}_{7}, 0.58 \mathrm{~mol} / \mathrm{l} \mathrm{N} \mathrm{N}_{4} \mathrm{CS}$. Points - experimental, envelope line calculated, low line - difference between the calculated and experimental values. Dashes - peak positions, upper ones correspond to crystal structure $B 1$-type, lower ones, to $\mathrm{TiO}_{2}$, which enters in the glass-ceramic composition
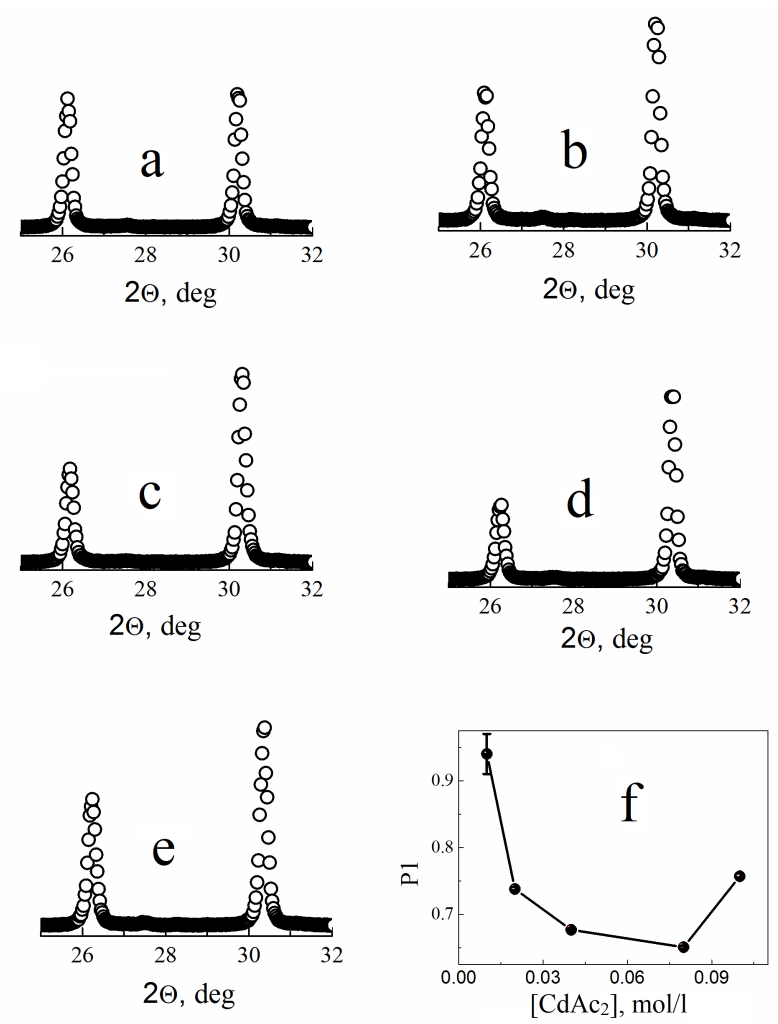

FIG. 3. Reflections (111) and (200) of $\mathrm{Cd}_{x} \mathrm{~Pb}_{1-x} \mathrm{~S}$ solid-solution films deposited on glassceramic substrate from the ammonium-citrated reaction bath with various cadmium acetate content: 0.01 (a), 0.02 (b), 0.04 (c), 0.08 (d), 0.1 (e) mol/1 volume of random-orientated material (f)

microdeformations in the films. Fig. 5 shows reflections (220) of the $\mathrm{Cd}_{x} \mathrm{~Pb}_{1-x} \mathrm{~S}$ solid-solution films deposited from the reaction mixtures containing different cadmium acetate concentrations in the range from 0.01 to $0.10 \mathrm{~mol} / \mathrm{l}$.

The shift of the angular position of reflections (220) with changing the cadmium acetate concentration corresponds to the change in the crystal lattice parameter of the $\mathrm{Cd}_{x} \mathrm{~Pb}_{1-x} \mathrm{~S}$ solid solution films. The value of broadening was calculated by $\beta(2 \theta)=\left[\left(\mathrm{FWHM}_{\text {exp }}\right)^{2}-\left(\mathrm{FWHM}_{R}\right)^{2}\right]^{1 / 2}$, where $\mathrm{FWHM}_{\text {exp }}$ is the experimental 

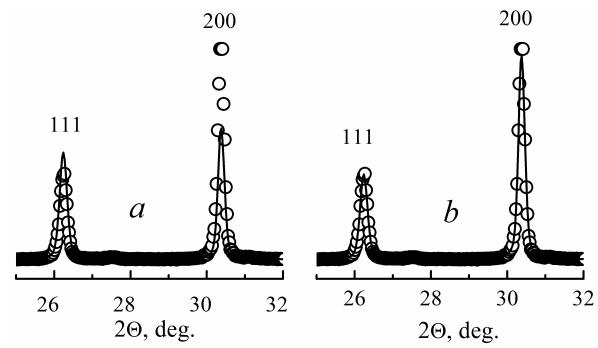

FIG. 4. XRD pattern segment of solid-solution film. Experimental (points) and calculated (solid lines) diffraction peaks (111) and (200) without account (a) and with account for preferable orientation (b)

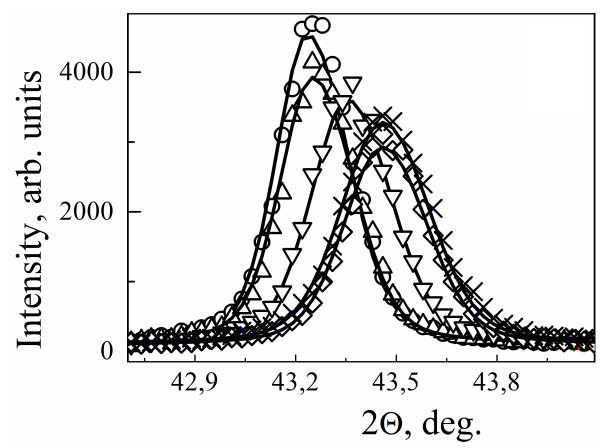

FIG. 5. Reflections (220) of $\mathrm{Cd}_{0.03} \mathrm{~Pb}_{0.97} \mathrm{~S}$ (circle), $\mathrm{Cd}_{0.06} \mathrm{~Pb}_{0.94} \mathrm{~S}$ (triangle up), $\mathrm{Cd}_{0.12} \mathrm{~Pb}_{0.88} \mathrm{~S}$ (triangle down), $\mathrm{Cd}_{0.20} \mathrm{~Pb}_{0.80} \mathrm{~S}$ (rhombus), $\mathrm{Cd}_{0.22} \mathrm{~Pb}_{0.78} \mathrm{~S}$ (cross) solid-solution films produced by deposition from reaction mixtures containing $0.01,0.02,0.04,0.08,0.10 \mathrm{~mol} / 1 \mathrm{of}$ cadmium acetate $\mathrm{CdAc}_{2}$

full-width of reflection at its half- height. The separation of dimensional and deformation contributions into the reflection broadening and the estimation of the average size of the coherent scattering region, which is considered as the average grain size $(L)$, were made by the Williamson-Hall extrapolation method [51,52] according to the dependence of the resulting broadening $\beta(\theta) \cos \theta=f(\sin \theta)$.

The reflection broadening connected with the small grain size is proportional to $\sec \theta$, whereas the broadening connected with microstrains is proportional to $\tan \theta$ [56], i.e. they have different angular dependence (here $\theta$ is the diffraction angle). In the dependence $\beta(\theta) \cos \theta=f(\sin \theta)$ (Fig. 6), given for the solid solution film $\mathrm{Cd}_{0.20} \mathrm{~Pb}_{0.80} \mathrm{~S}$, the line slope characterizes the amount of microstrains, while the intercept on the $\beta(\theta) \cos \theta$ axis upon extrapolation on the $\sin \theta$ axis gives the grain size $(L)$, which can be calculated using the Selyakov-Sherrer formula $L=k \lambda / \beta(\theta) \cos \theta$, where the coefficient $k$ is close to 1 and depends on the grain shape.

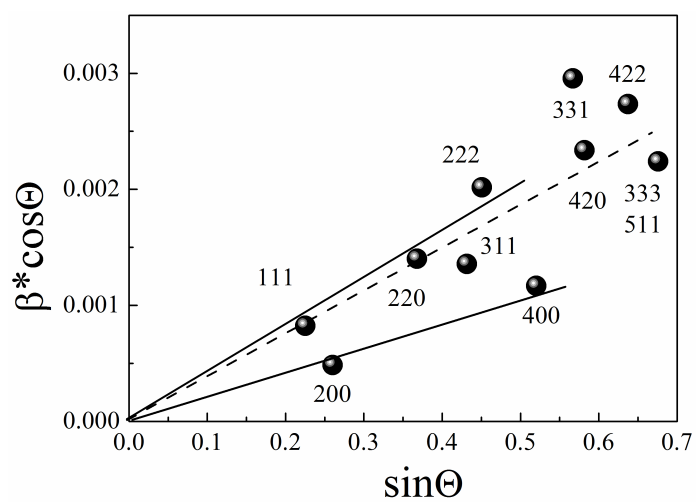

FIG. 6. Experimental $\beta(\theta) \cos \theta$ versus $\sin \theta$ dependence for the $\mathrm{Cd}_{0.20} \mathrm{~Pb}_{0.80} \mathrm{~S}$ solid-solution film 
According to the estimation of the experimental dependence $\beta(\theta) \cos \theta=f(\sin \theta)$ for the $\mathrm{Cd}_{0.20} \mathrm{~Pb}_{0.80} \mathrm{~S}$ solidsolution film, it can be concluded that the average values of $\beta(\theta) \cos \theta$ are close to 0 at $\sin \theta$ tending to zero. This indicates that the reflection broadening is mainly connected with the appearance of microstrains $\Delta d / d$ in the solid-solution film $\mathrm{Cd}_{0.20} \mathrm{~Pb}_{0.80} \mathrm{~S}$ in the course of chemical deposition. Moreover, irregularity in the localization of points in the figure testifies to the anisotropy of microstrains along different crystallographic directions. Actually, if we connect the points for dimensional crystallographic directions [hhh] and [h00] with the straight line in Fig. 6, it can be seen that the slope angle differs indicating various values of microstrains along these directions. Similar studies were performed for all synthesized $\mathrm{Cd}_{x} \mathrm{~Pb}_{1-x} \mathrm{~S}$ solid solution films. We can conclude that there is anisotropy of microstrains in the synthesized films. Taking into account this fact the analysis of all experimental XRD patterns for the $\mathrm{Cd}_{x} \mathrm{~Pb}_{1-x} \mathrm{~S}$ solid-solution films was made by Rietveld method [50] using software package FullProf [50] (Fig. 7).

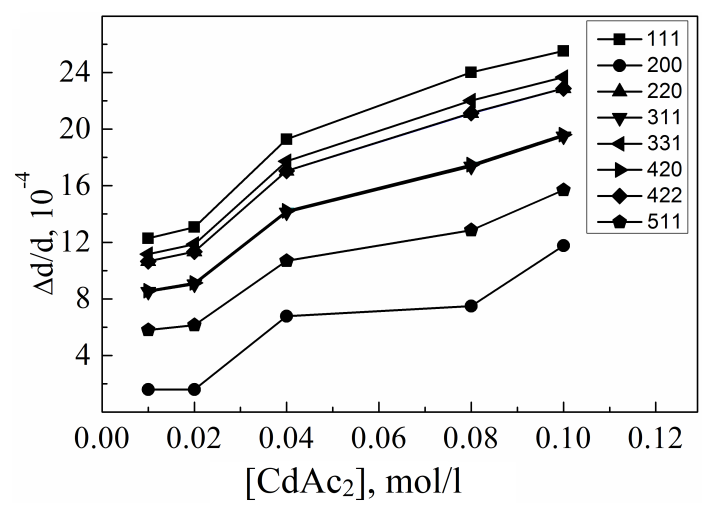

FIG. 7. Dependence the microstrains value $\Delta \mathrm{d} / \mathrm{d}$ in $\mathrm{Cd}_{x} \mathrm{~Pb}_{1-x} \mathrm{~S}$ solid solution films as a function of the cadmium acetate concentration in the reaction mixture

The results for the estimation of microstrains $\Delta d / d$ in the $\mathrm{Cd}_{x} \mathrm{~Pb}_{1-x} \mathrm{~S}$ solid-solution films show that the increasing the cadmium acetate concentration in the reaction mixture leads to an increase in microdeformations with approximately equal speed and anisotropy keeping in the microdeformation distribution in all studied thin film samples.

Thus, in the $\mathrm{Cd}_{x} \mathrm{~Pb}_{1-x} \mathrm{~S}(0.03 \leq x \leq 0.22)$ solid-solution films synthesized by chemical deposition from the ammonium-citrated reaction bath, is a crystal state with the $\mathrm{NaCl}(B 1)$ type lattice and a relatively large size of microcrystals is realized. The crystals have the preferable orientation [200] that is perpendicular to the substrate surface and are characterized by anisotropy of microstrains in the volume. As it was estimated above, the broadening of diffraction reflextions in the $\mathrm{Cd}_{x} \mathrm{~Pb}_{1-x} \mathrm{~S}$ solid-solution films are associated only with the appearance of microstrains in the sample bulk and can evidence the fact that the films were formed from grains with a size of $300-400 \mathrm{~nm}$ or more.

The microstructure investigation of the synthesized $\mathrm{Cd}_{x} \mathrm{~Pb}_{1-x} \mathrm{~S}$ films carried out upon varying the cadmium acetate content in the reaction mixture in the range $0.01-0.10 \mathrm{~mol} / 1$ and at fixed concentration $0.02 \mathrm{~mol} / 1 \mathrm{of}$ the lead salt showed that with an increase in the cadmium salt concentration in the solution both sizes and the microcrystal habit change (Fig. 8).

Herewith the morphology of the deposited films largely depends on the solid solution composition. Thus, the films based on $\mathrm{Cd}_{0.03} \mathrm{~Pb}_{0.97} \mathrm{~S}$ and $\mathrm{Cd}_{0.06} \mathrm{~Pb}_{0.94} \mathrm{~S}$ with the average size of crystallites $200-300 \mathrm{~nm}$ have a relatively high granular inhomogeneity. There are quite a number of nano-sized particles in their composition: less than $70-100 \mathrm{~nm}$. The increasing of the enrichment of solid solution in the substitutional component in the line $\mathrm{Cd}_{0.09} \mathrm{~Pb}_{0.91} \mathrm{~S}, \mathrm{Cd}_{0.12} \mathrm{~Pb}_{0.88} \mathrm{~S}, \mathrm{Cd}_{0.20} \mathrm{~Pb}_{0.80} \mathrm{~S}$ leads to the formation of well-bounded crystals with the average gross-sizes of $500-1000 \mathrm{~nm}$. However, the X-ray investigation of the diffraction peak width using Scherrer formula showed that the films are nanostructured with $50-70 \mathrm{~nm}$ particles. It is the result of the intercluster growth mechanism proved by us, which occurs at the bath deposition of metal chalcogenide films [33]. The proof of the nanostructural character of the deposited layers is also the film based on $\mathrm{Cd}_{0.22} \mathrm{~Pb}_{0.78} \mathrm{~S}$ solid solution shown in Fig. 8f. It is clearly seen that the film preliminary consists of $200-300 \mathrm{~nm}$ globules, which in turn are formed from $50-60 \mathrm{~nm}$ particles. It should be noted that nanostructural character of precursory layers of hydrochemically deposited sulfides is also mentioned in [57].

The smallest size of crystal grain $(200-400 \mathrm{~nm})$ was observed in the $\mathrm{Cd}_{0.03} \mathrm{~Pb}_{0.97} \mathrm{~S}$ solid-solution film formed from the initial particles with a size of $\sim 100 \mathrm{~nm}$. With increasing the cadmium acetate concentration 

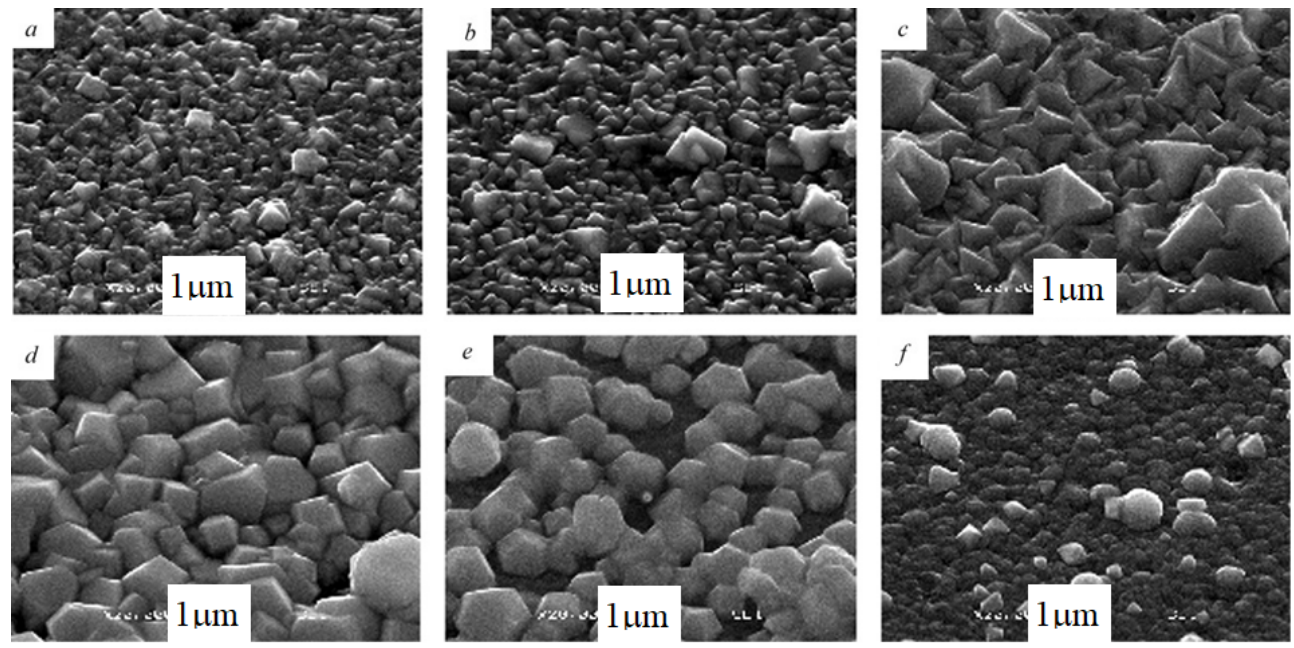

FIG. 8. Electron micrographs of $\mathrm{Cd}_{0.03} \mathrm{~Pb}_{0.97} \mathrm{~S}$ (a), $\mathrm{Cd}_{0.06} \mathrm{~Pb}_{0.94} \mathrm{~S}$ (b), $\mathrm{Cd}_{0.09} \mathrm{~Pb}_{0.91} \mathrm{~S}$ (c), $\mathrm{Cd}_{0.12} \mathrm{~Pb}_{0.88} \mathrm{~S}(\mathrm{~d}), \mathrm{Cd}_{0.20} \mathrm{~Pb}_{0.80} \mathrm{~S}$ (e), $\mathrm{Cd}_{0.22} \mathrm{~Pb}_{0.78} \mathrm{~S}$ (f) solid solution films produced by chemical deposition from reaction mixtures containing: $\left[\mathrm{PbAc}_{2}\right]=0.02 \mathrm{M},\left[\mathrm{Na}_{3} \mathrm{C}_{6} \mathrm{H}_{5} \mathrm{O}_{7}\right]=0.3 \mathrm{M}$, $\left[\mathrm{NH}_{4} \mathrm{OH}\right]=4.5 \mathrm{M},\left[\mathrm{N}_{2} \mathrm{H}_{4} \mathrm{CS}\right]=0.58 \mathrm{M}$. Cadmium acetate content $\left(\mathrm{CdAc}_{2}\right)$ is $0.01 \mathrm{M}$ (a), $0.02 \mathrm{M}(\mathrm{b}), 0.04 \mathrm{M}(\mathrm{c}), 0.06 \mathrm{M}$ (d), $0.08 \mathrm{M}$ (e), $0.10 \mathrm{M}$ (f). The synthesis was carried out at $353{ }^{\circ} \mathrm{C}$ for 140 minutes

in the reaction bath from 0.02 to $0.08 \mathrm{~mol} / \mathrm{l}$, the average size of well-bounded crystals increased from 300 $500 \mathrm{~nm}$ for the $\mathrm{Cd}_{0.06} \mathrm{~Pb}_{0.94} \mathrm{~S}$ films to $500-1000 \mathrm{~nm}$ for the layers based on $\mathrm{Cd}_{0.09} \mathrm{~Pb}_{0.91} \mathrm{~S}, \mathrm{Cd}_{0.12} \mathrm{~Pb}_{0.88} \mathrm{~S}$, and $\mathrm{Cd}_{0.20} \mathrm{~Pb}_{0.80} \mathrm{~S}$.

The $\mathrm{Cd}_{x} \mathrm{~Pb}_{1-x} \mathrm{~S}(0.03 \leq x \leq 0.09)$ solid-solution films have a clear texture: at the concentration of cadmium fraction of $0.03-0.09$, the crystals have the cube habit and grow on by the plane [111]. Agglomerates, from which the solid solution films $\mathrm{Cd}_{0.12} \mathrm{~Pb}_{0.88} \mathrm{~S}$ and $\mathrm{Cd}_{0.20} \mathrm{~Pb}_{0.80} \mathrm{~S}$ were formed, in the course of growing transformed into hexahedrons.

In general, the results of the average size estimation of crystallites that form the $\mathrm{Cd}_{x} \mathrm{~Pb}_{1-x} \mathrm{~S}$ solid-solution films by X-ray diffraction method and electron microscopy method are in a very good agreement with each other.

Keeping in mind the semiconductive character of the deposited $\mathrm{Cd}_{x} \mathrm{~Pb}_{1-x} \mathrm{~S}$ films, we can receive important information on their composition from the study of their conductivity. The investigation of film the conductivity performed upon varying the cadmium acetate concentration in the reaction bath in coordinates $\ln \sigma-f\left(\left[\mathrm{CdAc}_{2}\right]\right)$ indirectly confirmed the formation of substitutional solid solutions $\mathrm{Cd}_{x} \mathrm{~Pb}_{1-x} \mathrm{~S}$ upon co-deposition of the lead and cadmium sulfides from the ammonium-citrated reaction mixture. With the formation of solid solutions, the semiconductivity of films will decrease due to the increase in the bandgap width upon the substitution of lead in the $\mathrm{PbS}$ structure by cadmium ions. Actually, Fig. 9 shows that the conductivity of the $\mathrm{Cd}_{x} \mathrm{~Pb}_{1-x} \mathrm{~S}$ films is essentially lower than the conductivity of $\mathrm{PbS}$ and continues to decrease with increasing cadmium content in the solid-solution structure of $\mathrm{Cd}_{0.03} \mathrm{~Pb}_{0.97} \mathrm{~S}, \mathrm{Cd}_{0.09} \mathrm{~Pb}_{0.91} \mathrm{~S}$, and $\mathrm{Cd}_{0.12} \mathrm{~Pb}_{0.88} \mathrm{~S}$.

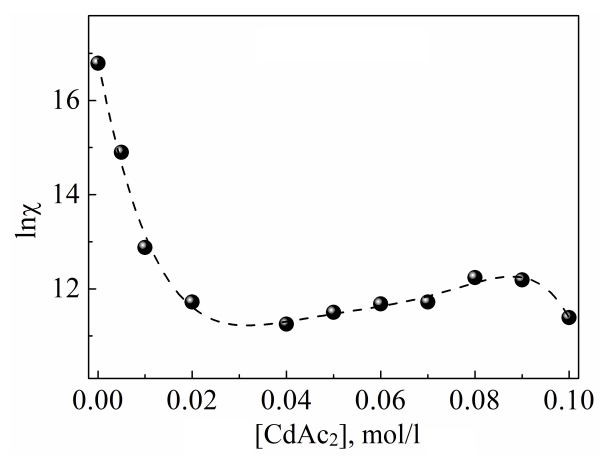

FIG. 9. Dependence of conductivity $\chi$ of $\mathrm{Cd}_{x} \mathrm{~Pb}_{1-x} \mathrm{~S}$ solid-solution films versus cadmium acetate concentration in the reaction mixture in coordinates " $\ln \chi-\left[\mathrm{CdAc}_{2}\right]$ " 
Such a situation is realized in semiconductors with the prevailing covalent bond and with preferable scattering of carriers on the lattice sound vibration, which is characteristic of both lead and cadmium sulfides [58,59].

The $\mathrm{Cd}_{x} \mathrm{~Pb}_{1-x} \mathrm{~S}$ solid-solution films of various compositions are photosensitive in the visible and near-infrared spectral range. It does not require sensabilization after their removal from the reaction mixture and are ready for practical use. The range of spectral sensitivity of the substitutional $\mathrm{Cd}_{x} \mathrm{~Pb}_{1-x} \mathrm{~S}$ alloys depends on their composition.

Figure 10 shows typical spectral characteristics of the $\mathrm{Cd}_{x} \mathrm{~Pb}_{1-x} \mathrm{~S}$ films with different cadmium sulfide content. It is clear that with increasing cadmium content $(x)$ in the solid-solution structure, a gradual shift occurs for the spectral characteristics toward the short-wave region. As shown in Fig. 10, with an increase in the cadmium fractional concentration in the $\mathrm{Cd}_{x} \mathrm{~Pb}_{1-x} \mathrm{~S}$ solid solution from 0.03 to 0.22 , the critical frequency and the photo response maximum moves to the short-wave range from 3.1 to $1.6 \mu \mathrm{m}$ and from 2.5 to $1.2 \mu \mathrm{m}$, respectively.
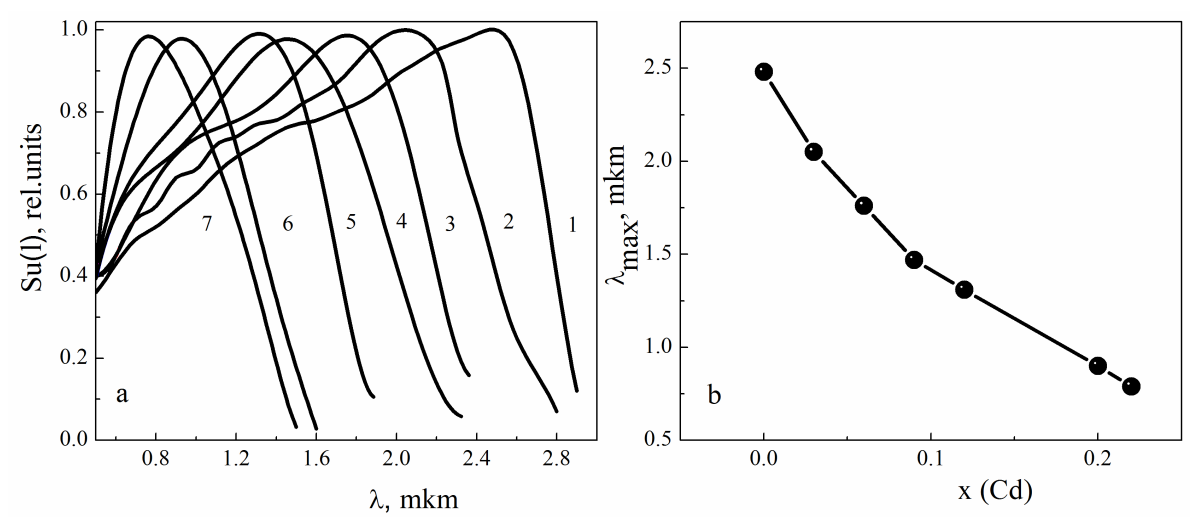

FIG. 10. (a) - Plots of relative spectral photosensitivity of films based on $\mathrm{PbS}(1)$ and $\mathrm{Cd}_{x} \mathrm{~Pb}_{1-x} \mathrm{~S}$ solid solutions of various composition: $\mathrm{Cd}_{0.03} \mathrm{~Pb}_{0.97} \mathrm{~S}(2), \mathrm{Cd}_{0.06} \mathrm{~Pb}_{0.94} \mathrm{~S}(3), \mathrm{Cd}_{0.09} \mathrm{~Pb}_{0.91} \mathrm{~S}$ (4), $\mathrm{Cd}_{0.12} \mathrm{~Pb}_{0.88} \mathrm{~S}(5), \mathrm{Cd}_{0.20} \mathrm{~Pb}_{0.80} \mathrm{~S}(6), \mathrm{Cd}_{0.22} \mathrm{~Pb}_{0.78} \mathrm{~S}$ (7). (b) - Change of the maximum position of photo response for the $\mathrm{Cd}_{x} \mathrm{~Pb}_{1-x} \mathrm{~S}$ solid-solution films depending on $x$

In general, the means of synthesizing $\mathrm{Cd}_{x} \mathrm{~Pb}_{1-x} \mathrm{~S}$ solid-solution films with various compositions and specific properties provides an opportunity to produce photosensitive semiconductive materials with the controlled maximum position and threshold of spectral sensitivity over the whole near-infrared range. The $\mathrm{Cd}_{0.06} \mathrm{~Pb}_{0.94} \mathrm{~S}$ solid solution has attracted special attention because its spectral characteristic practically similar to single-crystalline germanium but with higher ohmic resistance, thus providing easy compatibility in electron circuits.

\section{Conclusions}

Substitutional $\mathrm{Cd}_{x} \mathrm{~Pb}_{1-x} \mathrm{~S}$ solid solution films based on the cubic lattice of $\mathrm{PbS}$ with the thickness $0.6-1.2 \mu \mathrm{m}$ were produced by chemical bath co-deposition of lead and cadmium sulfides in the ammonium citrate reaction mixture on glass-ceramic substrates. With an increase in the concentration of cadmium acetate from 0.01 to $0.10 \mathrm{~mol} / 1$, the monotonous increase in the $\mathrm{CdS}$ content in the solid solutions obtained from 3.0 to 22.0 mol.\%. Comparison of the determined $\mathrm{Cd}_{0.03} \mathrm{~Pb}_{0.97} \mathrm{~S}, \mathrm{Cd}_{0.06} \mathrm{~Pb}_{0.94} \mathrm{~S}, \mathrm{Cd}_{0.09} \mathrm{~Pb}_{0.91} \mathrm{~S}, \mathrm{Cd}_{0.12} \mathrm{~Pb}_{0.88} \mathrm{~S}, \mathrm{Cd}_{0.20} \mathrm{~Pb}_{0.80} \mathrm{~S}, \mathrm{Cd}_{0.22} \mathrm{~Pb}_{0.78} \mathrm{~S}$ compositions with the phase diagram for the $\mathrm{PbS}-\mathrm{CdS}$ system testifies to a significant supersaturation level of the cadmium content in the synthesized solid solutions. The films were formed from crystallites with the preferable orientation [200] perpendicular to the substrate surface and are characterized by a clear anisotropy in distribution of microdeformations over the bulk of all researched samples. With an increase in the cadmium acetate concentration in the reaction mixture, an increase in the microstrains $\Delta d / d$ was observed in the films of the deposited $\mathrm{Cd}_{x} \mathrm{~Pb}_{1-x} \mathrm{~S}$ solid solutions. Both sizes and crystal habit changed. The smallest crystal sizes $(200-400 \mathrm{~nm})$ are characteristic of the $\mathrm{Cd}_{0.03} \mathrm{~Pb}_{0.97} \mathrm{~S}, \mathrm{Cd}_{0.06} \mathrm{~Pb}_{0.94} \mathrm{~S}$ solid solution formed from the initial particles $\sim 100 \mathrm{~nm}$ in size. There are quite a number of nanometer-scaled particles in their composition: less than $70-100 \mathrm{~nm}$. Increasing the enrichment of solid solution in the substitutional component in the line $\mathrm{Cd}_{0.09} \mathrm{~Pb}_{0.91} \mathrm{~S}, \mathrm{Cd}_{0.12} \mathrm{~Pb}_{0.88} \mathrm{~S}, \mathrm{Cd}_{0.20} \mathrm{~Pb}_{0.80} \mathrm{~S}$ leads to the film formation of well-bounded crystals with the average gross-sizes of $500-1000 \mathrm{~nm}$. According to the X-ray research, they are nanostructured with an average size for the initial particles of $50-70 \mathrm{~nm}$. Films based on $\mathrm{Cd}_{0.22} \mathrm{~Pb}_{0.78} \mathrm{~S}$ primarily consist of $200-300 \mathrm{~nm}$ globules, which in turn are formed from $50-60 \mathrm{~nm}$ particles.

With an increase in the cadmium acetate concentration in the reaction bath, the average size of the well-bounded crystals increases from $300-500 \mathrm{~nm}$ for $\mathrm{Cd}_{0.06} \mathrm{~Pb}_{0.94} \mathrm{~S}$ to $500-1000 \mathrm{~nm}$ for the layers based on $\mathrm{Cd}_{0.09} \mathrm{~Pb}_{0.91} \mathrm{~S}$, $\mathrm{Cd}_{0.12} \mathrm{~Pb}_{0.88} \mathrm{~S}$, and $\mathrm{Cd}_{0.20} \mathrm{~Pb}_{0.80} \mathrm{~S}$. Results from estimating the crystal size from XRD and microscopic examination 
are similar. The data from conductivity measurements of the synthesized layers indirectly confirm the formation of substitutional $\mathrm{Cd}_{x} \mathrm{~Pb}_{1-x} \mathrm{~S}$ solid solutions. The synthesized $\mathrm{Cd}_{x} \mathrm{~Pb}_{1-x} \mathrm{~S}$ solid-solution films have photosensitivity in the visible and near-infrared spectral ranges, the ranges of their spectral sensitivity corresponding to their compositions. With an increase in the level of the lead substitution in the $\mathrm{PbS}$ lattice by cadmium, it was determined that the maximum of the spectral characteristic and the long-wave limit of photo response of the $\mathrm{Cd}_{x} \mathrm{~Pb}_{1-x} \mathrm{~S}$ films gradually moved toward the short-wave spectral range from 3.1 to $1.6 \mu \mathrm{m}$ and from 2.5 to $1.2 \mu \mathrm{m}$, respectively. The obtained results create a basis for the purposeful synthesis via chemical bath deposition of the $\mathrm{Cd}_{x} \mathrm{~Pb}_{1-x} \mathrm{~S}$ solid-solution films with a specified composition in order to make semiconducting materials which have photosensitivity in the visible and near-infrared spectral ranges with variable spectral characteristics.

\section{Acknowledgements}

The work was supported by Act 211 Government of the Russian Federation, contract No. 02.A03.21.0006. The research was carried out in part at IMP Neutron Material Science Complex within the state assignment of FASO of Russia (theme "Flux" No. AAAA-A18-118020190112-8).

\section{References}

[1] Kumar S., Bhattacharya B. Variation of band gap in CdPbS with composition prepared by a precipitation technique. Indian J. Pure Appl. Phys., 2005, 43, P. 609-611.

[2] Barote M.A., Yadav A.A., Masumdar E.U. Effect of deposition parameters on growth and characterization of chemically deposited $\mathrm{Cd}_{1 x} \mathrm{~Pb}_{x} \mathrm{~S}$ thin films. Chalcogenide Letters, 2011, 8, P. 129-138.

[3] Kamruzzman M., Dutta R., Podder J. Synthesis and characterization of the as-deposited $\mathrm{Cd}_{1 x} \mathrm{~Pb}_{x} \mathrm{~S}$ thin films prepared by spray pyrolysis technique. Semiconductors, 2012, 46, P. 957-961.

[4] Al-Jumaili H.S. Structural and optical properties of nanocrystalline $\mathrm{Pb}_{1 x} \mathrm{Cd}_{x} \mathrm{~S}$ thin films prepared by chemical bath deposition. Appl. Phys. Research, 2012, 4, P. 75-82.

[5] Tan G.-L., Liu L., Wu W. Mid-IR band gap engineering of $\mathrm{Cd}_{x} \mathrm{~Pb}_{1-x} \mathrm{~S}$ nanocrystals by mechanochemical reaction. AIP Advances, 2014, 4, 067107.

[6] Maskaeva L.N., Markov V.F., Porkhachev M.Yu., Mokrousova O.A. Thermal and radiation stability IR-detectors based on films of solid solutions $\mathrm{CdPb}_{1-}$ S. Fire and Explosion Safety, 2015, 9, P. 67-73.

[7] Chu T.L., Chu S.S., et al. High efficiency thin film CdS/CdTe heterojunction solar cells. J. Cryst. Growth, 1992, 117, P. $1073-1076$.

[8] Ferekides C., Britt J. CdTe solar cells with efficiencies over 15\%. Sol. Energy Mater. Sol. Cells, 1994, 35, P. $255-262$.

[9] Uda H., Ikegami S., Sonomura H. Effect of substrate temperature on the photovoltaic properties of a CdS/CdTe solar cell. Japanese J. Appl. Phys., 1990, 29, P. 2003-2007.

[10] Bairamov B.Kh., Nikolaev Yu.A., et al. Effect of electron irradiation on the photopleochroism of $\mathrm{ZnO} / \mathrm{CdS} / \mathrm{Cu}(\mathrm{In}, \mathrm{Ga}) \mathrm{Se} 2$ solar cells. Tech Phys. Lett., 2005, 31, P. 698-701.

[11] Hernadez-Borja J., Vorobiev Y.V., Ramirez-Bon R. Thin films solar cells of CdS/PbS chemically deposited by an ammonia - free process. Solar Energy Materials \& Solar Cells, 2011, 95, P. 1882-1888.

[12] Obaid A.S., Mahdi M.A., Hassan Z., Bououdina M. Preparation of chemically deposited thin films of CdS/PbS solar cell. Superlattices and Microstructures, 2012, 52, P. 816-823.

[13] Yeon D.H., Lee S.M., et al. Origin of the enhanced photovoltaic characteristics of PbS thin film solar cells processed at near room temperature. J. Mater. Chem. A, 2014, 2, P. 20112-20117.

[14] Peña-Cabrera L., Arizmendi-Morquecho A., Vorobiev P. Thin film CdS/PbS solar cell by low temperature chemical bath deposition and silver doping of the window layer. J. of Non-Oxide Glasses, 2016, 8, P. 59-66.

[15] Saikia D., Phukan P., Das M.R. Influence of thickness of active layer on the performance of CBD grown Cu-CdS/PbS hetero-junction. Adv. Mater. Lett., 2017, 8, P. 65-69.

[16] Caselli D.A., Ning C.Z., High-performance laterally-arranged multiple-bandgap solar cells using spatially composition-graded $\mathrm{Cd}_{x} \mathrm{~Pb}_{1-x} \mathrm{~S}$ nanowires on a single substrate: a design study. Optics Express A, 2011, 19, P. 686-694.

[17] Rokakh A.G., Stetsyura S.V., Trofimova N.B., Elagina N.V. Stabilizing effect of doping with $\mathrm{PbS}_{\text {on }}$ properties of CdS $\mathrm{Se}_{1-x}$ wide-gap photoconductors. Inorg. Mater., 1999, 35, P. 452-454.

[18] Bethke P.M., Barton P.B. Sub-solidus relations in the system PbS-CdS. American Mineralogist, 1971, 56, P. $2034-2039$.

[19] Rokakh A.G., Stetsyura S.V., Serdobintsev A.A. Heterophase semiconductors under action of radiations. Izvestiya of Saratov University. New Series. Series: Physics, 2005, 5, P. 98-101.

[20] Bukharov V.E., Rokakh A.G., Stetsyura S.V. Diffusion degradation model for a heterogeneous photoconducting system. Tech. Phys., 2003, 48, P. 225-230.

[21] Rokakh A.G., Trofimova N.B. On luminescence enhancement in narrow-gap phase of PbS-CdS heterogeneous semiconductor. Tech. Phys., 2001, 46, P. 926-928.

[22] Bukharov V.E., Rokakh A.G., Stetsyura S.V. Influence of electron bombardment on recombination and attachment in II-VI - IV-VI film photoconductors. Tech. Phys. Lett., 1999, 25, P. 111-113.

[23] Bukharov V.E., Rokakh A.G. Influence of defect diffusion on radiation resistance of the heterogeneous photoconductor CdS-PbS. Tech. Phys. Lett., 1999, 25, P. 994-996.

[24] Malyar I.V., Stetsyura S.V. The effect of morphology and surface composition on radiation resistance of heterogeneous material CdS-PbS. Semiconductors, 2011, 45, P. 888-893.

[25] Markov V.F., Kitaev G.A., Ujmin S.N., Maskaeva L.N. Chemical technique of thin film synthesis of photosensitive materials. Photo resistors of visible and IR-range. Innovation, 1998, 1, P. 55-56. 
[26] Barote M.A., Yadav A.A., Chavan T.V., Masumdarb E.U. Characterization and photoelectrochemical properties of chemical bath deposited n-PbS thin films. Digest Journal of Nanomaterials and Biostructures, 2011, 6, P. 979-990.

[27] Mohammed M.A., Mousa A.M., Ponpon J.P. Optical and optoelectric properties of PbCdS ternary thin films deposited by CBD. J. of Semiconductor Technology and Science, 2009, 9, P. 117-123.

[28] Shelimova L.E., Tomashik V.N., Gricyv V.I. Phase diagrams in semiconducting material science (systems based on Si, Ge, Sn, Pb). Nauka, Moscow, 1991.

[29] Vesnin Yu.I. On threshold temperature of solid substitutional solution formation. Izvestiya of SB AS USSR. Series Chem. Sc., 1987, 17, P. 145-149.

[30] Vesnin Yu. I. On formation mechanism of substitutional solid solutions. Izvestiya of SB AS USSR. Series Chem. Sc., 1985, 15, P. 7-10.

[31] Markov V.F., Maskaeva L.N., Kitaev G.A. Predicting the composition of $\mathrm{Cd}_{x} \mathrm{~Pb}_{1 x} \mathrm{~S}$ films deposited from aqueous solutions. Inorg. Mater., 2000, 36, P. 1194-1196.

[32] Markov V.F., Maskaeva L.N., Polikarpova Yu.S. Films of supersaturated $\mathrm{Cd}_{x} \mathrm{~Pb}_{1-x} \mathrm{~S}$ solid solutions deposited on porous glass, their structure and properties. Butlerov Communications, 2006, 8, P. 54-61.

[33] Markov V.F., Maskaeva L.N., Ivanov P.N. Chemical bath deposition of metal sulfide films: modeling and experiment. UB RAS, Yekaterinburg, 2006.

[34] Kirsanov A.Yu., Markov V.F., Maskaeva L.N. Solid solution CdxPb1-xS forecasting by simulating of sulphides lead and cadmium co-precipitation process. Bulletin of the South-Ural State University. Series "Chemistry”, 2013, 5, P. 35-39.

[35] Rabinovich E., Wachtel E., Hodes G. Chemical bath deposition of single-phase (Pb,Cd)S solid solutions. Thin solid films, 2008, 517, P. 737-744.

[36] Markov V.F., Maskaeva L.N. Calculating the boundary conditions of the formation of solid-phase metal sulfides and selenides by deposition with thio- and selenourea. Russian J. of Phys. Chem. A, 2010, 84, P. 1288-1293.

[37] Nichols P.L., Liu Z., et al. $\mathrm{Cd}_{x} \mathrm{~Pb}_{1-x} \mathrm{~S}$ alloy nanowires and heterostructures with simultaneous emission in mid-infrared and visible wavelengths. Nano Lett., 2015, 15, P. 909-916.

[38] Suryavanshi K.E., Dhake R.B., Patil A.M. Optical properties of PbxCd1xS thin films prepared by chemical bath deposition method. Int. J. of Advanced Scientific and Technical Research, 2014, 2, P. 858-861.

[39] Osuwa J.C., Oriaku C.I., Ezema F.I. Impurity effects of cadmium salt on the absorption edge and structure of chemically prepared PbS films. Chalcogenide Lett., 2009, 6, P. 385-391.

[40] Deo S.R., Singh A.K., et al. Studies on structural, morphological and optical behavior of chemically deposited $\mathrm{Cd}_{0.5} \mathrm{~Pb}_{0.5} \mathrm{~S}$ thin films. Int. J. for Light and Electron Optics, 2015, 126, P. 2311-2317.

[41] Ahmad S.M., Kasim S.J., Latif L.A. Effects of thermal annealing on structural and optical properties of nanocrystalline $\mathrm{Cd}_{x} \mathrm{~Pb}_{1-x} \mathrm{~S}$ thin films prepared by CBD. Jordan J. of Physics, 2016, 9, P. 113-122.

[42] Pentia E., Draghici V., et al. Structural, electrical, and photoelectrical properties of $\mathrm{Cd}_{x} \mathrm{~Pb}_{1-x} \mathrm{~S}$ thin films prepared by chemical bath deposition. J. of the Electrochemical Society G, 2004, 151, P. 729-733.

[43] Nayak B.B., Acharya H.N. Characterization of chemically deposited $\mathrm{Pb}_{1-x} \mathrm{Cd}_{x} \mathrm{~S}$ films by scanning electron microscopy. J. of Materials Science Lett., 1985, 4, P. 651-652.

[44] Bhushan S., Mukherjee M., Bose P. Electro-optical studies in chemically deposited La/Nd doped (Cd-Pb) S films. J. of Material Science Materials in Electronics, 2002, 13, P. 581-584.

[45] Omotoso E., Adegboyega G.A., et al. Synthesis and some properties of MOCVD lead sulphide and lead cadmium sulphide thin films. $J$. Non-Oxide Glasses, 2013, 5, P. 9-19.

[46] Belov N.V. Processes of grain formation. Nauka, Moscow, 1977.

[47] Chavez H., Jordan M., et al. Physical and electrical characterization of CdS deposited by vacuum evaporation, solution growth and spray pyrolysis. J. Mater. Sci.: Mater. Electronics, 1997, 8, P. 151-154.

[48] Makurin Yu.N., Pletnev R.N., Kleshchev D.G., Zhelonkin N.A. Intermediate complex in chemical reactions. UB AS USSR, Sverdlovsk, 1990.

[49] Rietveld H.M. A profile refinement method for nuclear and magnetic structures. J. Appl. Crystallogr., 1969, 2, P. 65-71.

[50] Rodriguez-Carvajal J. Recent advances in magnetic structure determination by neutron powder diffraction. Physica B: Condensed Matter, 1993, 192, P. 55-69.

[51] Hall W.H., Williamson G.K. The diffraction pattern of cold worked metals: I the nature of extinction. Proceedings of the Physical Society. Section B, 1951, 64, P. 937-946.

[52] Williamson G.K., Hall W.H. X-ray line broadening from filed aluminium and wolfram. Acta metallurgica, 1953,1 , P. $22-31$.

[53] Muhamedyarov R D., Stuk V.I., Blinov O.Yu. Device for measuring threshold parameters of photo detectors. Instruments and Experimental Techniques, 1976, 6, P. 234.

[54] Chichagov A.V., Sipavina L.V. Parametaers of solid solution cells. Nauka, Moscow, 1982.

[55] Qadri S.B., Singh A., Yousuf M. Structural stability of PbS films as a function of temperature. Thin Solid Films, 2003, 431, P. 506-510.

[56] Kitajgorodskij A.I. X-ray structure analysis of fine-crystalline and amorphous materials. GITTL, Leningrad, 1952.

[57] Kozhevnikova N.S., Vorokh A.S., et al. Synthetic path way of a $\mathrm{Cu}_{2} \mathrm{ZnSnS}_{4}$ powder using low temperature annealing of nanostructured binary sulfides. Nanosystems: Phys., Chem., Math., 2017, 8 (6), P. 787-792.

[58] Abrikosov N.Kh., Bankina V.F., et al. Semiconducting chalcogenides and their alloys. Nauka, Moscow, 1982.

[59] Blakemore J.S. Solid State Physics. Second ed., Cambridge University Press, Cambridge, 1985, 506 pp. 